\title{
Hegemoni Patriarki Publik Terhadap Tokoh Perempuan dalam Novel "Hanauzumi" Karya Junichi Watanabe
}

\author{
Retno Putri Utamia1, Endry Boeriswati ${ }^{\mathrm{a} 2}$, dan Zuriyati Zuriyati ${ }^{\mathrm{a}}$ \\ ${ }^{a}$ Universitas Negeri Jakarta, Indonesia \\ ${ }^{1}$ neno2814@gmail.com; ${ }^{2}$ endry.boeriswati@unj.ac.id; ${ }^{3}$ zuriyati_adab@yahoo.com
}

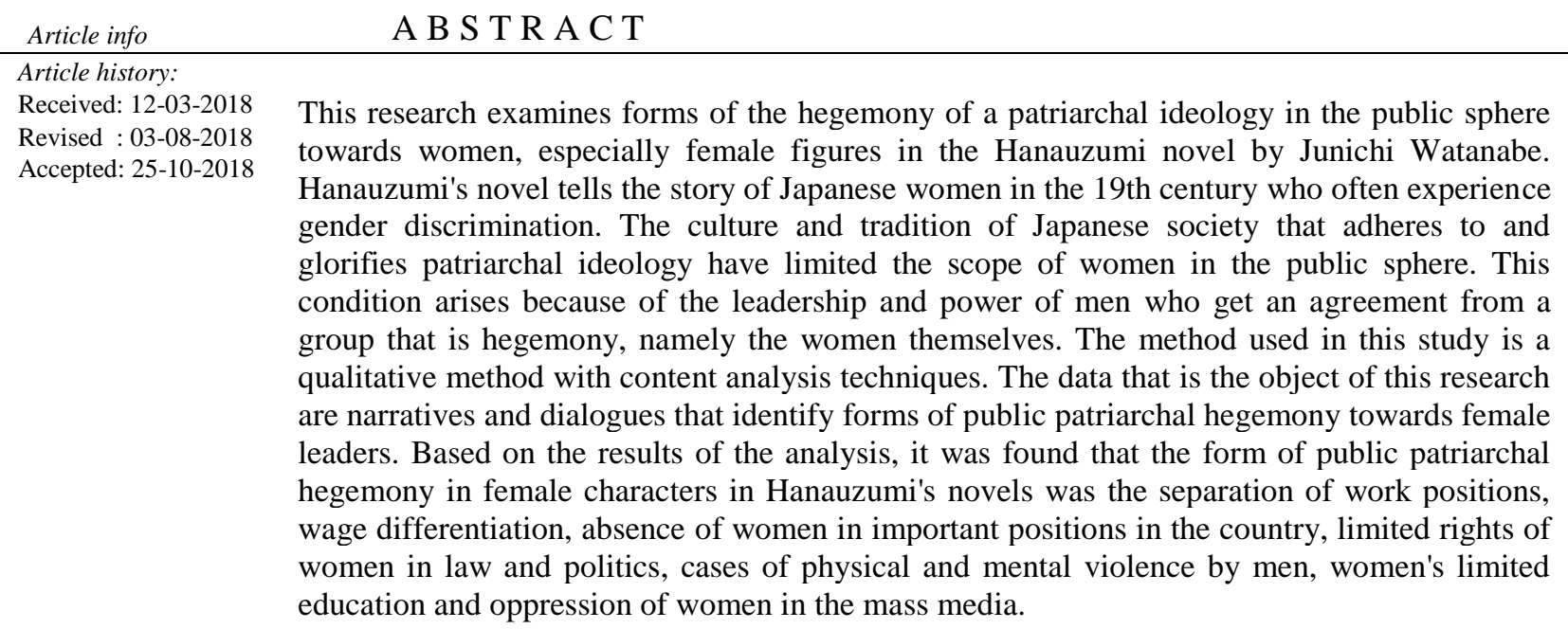

Keywords:

hegemony

Japan

novel

patriarchy

women
Penelitian ini bertujuan mengkaji bentuk-bentuk hegemoni suatu ideologi patriarki di bidang publik terhadap perempuan, khususnya tokoh perempuan dalam novel "Hanauzumi" karya Junichi Watanabe. Novel "Hanauzumi" menceritakan kisah kaum perempuan Jepang di abad 19 yang sering mengalami diskriminasi gender. Budaya dan tradisi masyarakat Jepang yang menganut dan mengagungkan ideologi patriarki mengakibatkan ruang lingkup kaum perempuan di ranah publik menjadi terbatas. Kondisi ini muncul karena adanya kepemimpinan dan kekuasaan kaum laki-laki yang mendapat kesepakatan dari kelompok yang dihegemoni, yaitu kaum perempuan itu sendiri. Metode yang digunakan dalam penelitian ini adalah metode kualitatif dengan teknik analisis isi. Data yang menjadi objek penelitian ini adalah narasi dan dialog yang mengidentifikasikan bentuk-bentuk hegemoni patriarki publik terhadap tokoh perempuan. Berdasarkan hasil analisis, ditemukan bahwa bentuk hegemoni patriarki publik pada tokoh perempuan dalam novel "Hanauzumi" berupa pemisahan posisi kerja, pembedaan upah, ketidakhadiran perempuan dalam posisi penting di negara, terbatasnya hak perempuan dalam bidang hukum dan politik, kasus kekerasan fisik dan mental oleh laki-laki, terbatasnya perempuan dalam pendidikan dan tertindasnya kaum perempuan dalam media massa.

\section{PENDAHULUAN}

Salah satu tujuan pembelajaran sastra adalah menumbuhkembangkan kepekaan terhadap masalah-masalah manusiawi, baik dalam konteks individual maupun kehidupan sosial. Salah satu tema karya sastra yang diangkat dari kehidupan nyata adalah adanya diskriminasi gender 


\section{Indonesian Language Education and Literature \\ e-ISSN: 2502-2261 \\ http://www.syekhnurjati.ac.id/jurnal/index.php/jeill/ \\ Vol. 4, No. 1, Desember 2018, 62-74}

(Mulyaningsih, 2015). Sebuah fenomena yang mengondisikan perempuan diletakkan sebagai makhluk kedua atau inferior dan laki-laki adalah kaum superior. Kondisi ini semakin mengakar dengan adanya sebuah istilah patriarki. Patriarki adalah sebuah ideologi dan simbol dari prinsip laki-laki; sebagai kekuatan untuk menunjukkan penguasaan laki-laki atas seksualitas dan fertilitas perempuan, serta untuk mendeskripsikan struktur institusional dari dominasi laki-laki (Kramarae, Treichler, dan Russo, 1985). Millet juga menyatakan bahwa ideologi patriarki dalam akademi, institusi keagaman, dan keluarga membenarkan dan menegaskan subordinasi perempuan terhadap laki-laki yang berakibat bagi kebanyakan perempuan untuk menginternalisasi diri terhadap laki-laki (Sofia, 2009). Di Jepang, ideologi patriarki diterapkan untuk mengatur sistem kemasyarakatan dan dianut dengan sangat kuat oleh semua kalangan masyarakat. Akibatnya, perempuan harus tunduk patuh pada laki-laki. Di zaman tersebut, ketika hendak makan, perempuan harus menunggu sampai para laki-laki selesai. Selain itu, perempuan harus berjalan beberapa langkah di belakang laki-laki. Perempuan juga harus selalu berbicara dengan hormat ketika menghadapi laki-laki. Ruang lingkup perempuan diharuskan terbatas hanya pada pekerjaan rumah tangga dan mengasuh anak. Akses perempuan sangat dibatasi, misalnya dalam pendidikan dan bekerja di luar rumah. Jalan terbuka untuk perempuan berkiprah di lembaga negara dan mendapat hak untuk berkontribusi di bidang publik seperti ranah hukum dan media massa pun sangat minim. Keluarga Jepang di zaman Meiji (1868-1912), seorang menantu perempuan memiliki status sangat rendah dan upah bagi pekerja perempuan juga adalah upah yang jauh lebih rendah dari laki-laki (Germer, 2006). Patriarki merupakan salah satu penyebab ketimpangan gender di Jepang yang kemudian memosisikan kaum perempuan lebih rendah dari laki-laki.

Walby (2014) membagi patriarki ke dalam beberapa struktur. Struktur patriarki ini berjalan terus-menerus dengan mentransmisikan kecenderungan praktik ketimpangan gender. Struktur-struktur patriarki menurut Walby adalah: a) patriarki dalam produksi rumah tangga yang berupa penugasan penuh bagi perempuan dalam mengasuh anak dan mengerjakan tugas rumah tangga; b) patriarki dalam pekerjaan dengan upah yang berupa pemisahan posisi kerja perempuan dan laki-laki serta perbedaan gaji; c) patriarki dalam negara yang berupa ketidakhadiran perempuan dalam posisi penting di pemerintahan serta terbatasnya perempuan 


\section{Indonesian Language Education and Literature \\ e-ISSN: 2502-2261 \\ http://www.syekhnurjati.ac.id/jurnal/index.php/jeill/ \\ Vol. 4, No. 1, Desember 2018, 62-74}

dalam berperan di bidang hukum dan politik; d) patriarki dalam seksualitas yang berupa posisi perempuan yang dianggap sebagai pemberi layanan seksual dan pemberi layanan emosional atau penyedia kasih sayang penuh; e) patriarki yang berkaitan dengan kekerasan laki-laki yang berupa kekerasan fisik, psikis, dan verbal; serta f) patriarki dalam budaya, yang berupa tuntutan 'feminin ideal' bagi perempuan dalam keluarga, pendidikan, agama, maupun media massa.

Patriarki dapat terjadi di dua wilayah, yaitu: privat atau rumah tangga dan publik. Walby (2014) membagi bentuk patriarki menjadi patriarki privat dan patriarki publik. Bentuk patriarki privat pada dasarnya menjadikan arena produksi rumah tangga dan keluarga sebagai arena utama penindasan terhadap perempuan. Sementara patriarki publik, pada dasarnya merupakan bentuk praktik penguasaan oleh ideologi patriarki pada arena public, seperti: pekerjaan dan negara. Struktur patriarki lain, seperti: budaya yang berkaitan dengan penguasaan laki-laki di bidang pendidikan dan media massa serta patriarki yang berikatan dengan kekerasan laki-laki terhadap perempuan.

Dalam kehidupan nyata, kokohnya patriarki tidak serta merta karena superioritas lakilaki yang dipaksakan secara brutal untuk menindas kaum perempuan. Menurut Darwin (1999), ideologi patriarki merupakan salah satu variasi dari ideologi hegemoni. Artinya, suatu ideologi yang membenarkan penguasaan satu kelompok terhadap kelompok lainnya dan diterima secara sukarela. Ideologi patriarki memiliki kecenderungan disetujui atau disepakati oleh kelompok inferior yang selanjutnya disebut sebagai kelompok yang terhegemoni. Istilah hegemoni berasal dari akar kata dalam bahasa Yunani yaitu, hegeistha, berarti memimpin, kepemimpinan, dan kekuasaan yang melebihi kekuasaan yang lain (Ratna, 2010). Hegemoni pada awalnya dikonsepkan oleh Antonio Gramsci sebagai kekuasaan dan supremasi suatu kelas sosial yang dicapai melalui kepemimpinan intelektual dan moral serta mendapat persetujuan dari kelompok yang dihegemoni (Patria dan Arief, 2003; Ratna, 2010). Penerapan hegemoni adalah sebagai bentuk dominasi kelas sosial tertentu (Bruce dan Yearley, 2006). Saat ini, hegemoni sering dimaknai secara sederhana sebagai 'pengaruh yang sungguh besar'. Makna ini lebih sempit daripada dominasi. Hegemoni lebih berfokus pada pengaruh ideologi dan memberi dampak berkurangnya sengketa atau perselisihan. 


\section{Indonesian Language Education and Literature \\ e-ISSN: 2502-2261 \\ http://www.syekhnurjati.ac.id/jurnal/index.php/jeill/ \\ Vol. 4, No. 1, Desember 2018, 62-74}

Berdasarkan berbagai konsep hegemoni, dapat dipahami bahwa hegemoni adalah suatu kepemimpinan dan supremasi sebuah kelas sosial dengan menggunakan pengaruh ideologi yang disepakati oleh kelas sosial tertentu. Suatu ideologi yang secara turun-temurun tetap bertahan kuat adalah patriarki. Hegemoni patriarkat atau patriarki terus-menerus disosialisasikan dari generasi ke generasi (Wiyatmi, 2012). Kokohnya ideologi patriarki dapat terjadi akibat adanya kesepakatan dari kelompok yang terhegemoni, yaitu kaum perempuan itu sendiri. Penelitian hegemoni patriarki bertujuan untuk mengkaji adanya kekuasaan lakilaki serta seperangkat ideologi patriarki yang disepakati oleh kaum perempuan. Perempuan menjadi tersubordinasi, khususnya di wilayah publik. Studi ini berbeda dengan kajian feminisme yang selama ini banyak diteliti.

Salah satu bidang kajian fenomena hegemoni patriarki di Jepang dapat ditelusuri dari berbagai literatur fiksi maupun nonfiksi. Sebuah novel biografi dari Jepang mengisahkan kekuasaan patriarki yang menindas perempuan dan hidup dalam kungkungan ideologi patriarki. Tokoh utama novel ini bernama Gin Ogino. Gin Ogina ditulari penyakit kelamin oleh suaminya hingga terpuruk dalam derita fisik serta mental. Namun, Gin Ogina dapat bermetamorfosis menjadi seorang dokter perempuan yang sukses. Novel ini juga banyak mengisahkan tokoh perempuan lain yang mengalami ketertindasan, baik fisik maupun mental di tengah-tengah kejayaan ideologi patriarki Jepang pada zaman Meiji.

Berdasarkan penjelasan dan latar belakang tersebut, penelitian ini bertujuan untuk mendeskripsikan bentuk-bentuk hegemoni patriarki publik yang terjadi di Jepang pada era abad 19. Studi mengenai hegemoni patriarki publik berusaha mengungkap adanya kondisi kesepakatan dari kelompok inferior yang terhegemoni sehingga menyebabkan ideologi patriarki ini bertahan terus-menerus dan tersubordinasinya kaum perempuan di wilayah publik.

\section{METODE}

Penelitian ini menggunakan metode kualitatif dengan teknik analisis isi (content analysis). Penelitian kualitatif mengandung pendekatan naturalistik dan interpretive (Denzin \& Lincoln, 2000). Adapun langkah yang dilakukan, meliputi: 1) mempelajari dan menganalisis bahan penelitian di lapangan, 2) menginterpretasi fenomena yang muncul dari 


\section{Indonesian Language Education and Literature \\ e-ISSN: 2502-2261 \\ http://www.syekhnurjati.ac.id/jurnal/index.php/jeill/ \\ Vol. 4, No. 1, Desember 2018, 62-74}

hasil penelitian, serta 3) mendeskripsikan dengan makna yang lebih terperinci kepada pembaca. Penelitian dengan perspektif feminisme ini akan lebih mengungkap permasalahan dan pemecahan fenomena sosial yang berkaitan dengan dunia feminisme dan hegemoni patriarki publik. Analisis data dengan teknik analisis isi, berupa kata-kata, frasa, kalimat, atau kutipan-kutipan serta wacana atau narasi yang mendeskripsikan dan merepresentasikan bentuk-bentuk hegemoni patriarki publik terhadap tokoh perempuan. Sumber data berupa novel Hanauzumi berbahasa Jepang karya Junichi Watanabe. Data sekunder berupa novel Ginko yang merupakan terjemahan novel Hanauzumi. Novel tersebut diterjemahkan oleh Istiani Prajoko berjudul. Data sekunder digunakan sebagai data pelengkap yang dapat membantu proses klarifikasi atau konfirmasi terhadap data primer. Adapun langkah-langkah penelitian ini, antara lain: (a) pengumpulan data kepustakaan yang relevan, (b) pembacaan secara intensif terhadap novel yang diteliti, (c) membuat catatan yang berisi deskripsi setiap peristiwa yang berkaitan dengan fokus dan subfokus penelitian, (d) mengidentifikasi aspekaspek yang merupakan tujuan penelitian dan melakukan inferensi serta menyesuaikan dengan teori relevan, serta (e) melakukan analisis dan interpretasi data.

\section{HASIL DAN PEMBAHASAN}

Bentuk-bentuk hegemoni patriarki publik terhadap tokoh perempuan dalam novel Hanauzumi karya Junichi Watanabe ini dikaji berdasarkan konsep hegemoni Gramsci dan struktur patriarki yang dicetuskan oleh Sylvia Walby. Struktur pada patriarki publik di antaranya adalah praktik berkuasanya patriarki di bidang pekerjaan dengan upah, penguasaan patriarki di negara, praktik kekerasan laki-laki terhadap perempuan di wilayah publik, dan berkuasanya patriarki dalam bidang budaya, seperti: penguasaan akses pendidikan maupun media massa. Hegemoni patriarki publik adalah konfigurasi kekuasaan yang menjamin posisi dominan laki-laki dan subordinasi perempuan pada wilayah publik, seperti: sektor pekerjaan dengan upah dan negara. Berdasarkan teori Sylvia Walby, struktur patriarki dalam kekerasan laki-laki dan budaya juga masih ditemukan dalam patriarki publik. 


\section{Indonesian Language Education and Literature e-ISSN: 2502-2261 \\ http://www.syekhnurjati.ac.id/jurnal/index.php/jeill/ \\ Vol. 4, No. 1, Desember 2018, 62-74}

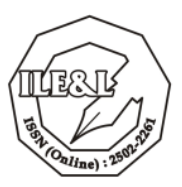

Hegemoni patriarki publik dalam bidang pekerjaan dengan upah. Bentuk hegemoni patriarki publik berikut ini merupakan sebuah konfigurasi kekuasaan patriarki dalam struktur pekerjaan dengan upah yang di dalamnya terdapat praktik ketimpangan seperti pemisahan posisi kerja dan pembedaan upah untuk perempuan.

1)「「考えてもみられよ、女子には妊娠という厄介なことがある。 その度に患者を手放さねばならん。これでは不安で、とても患者をまかせ るわけにはいかん。それに毎月、きまって污れる日もあろう。」

(Watanabe, 1970: 236)

"Jika kau berpikir, kau akan mengerti. Perempuan memiliki tugas untuk mengandung. Mereka harus meninggalkan pasien ketika hamil, dan kami tidak bisa memercayakan pasien atas ketidakstabilan semacam itu. Selain itu, setiap bulan pada hari-hari tertentu, perempuan itu kotor. Bukankah begitu?" (Watanabe, 2013: 204-205).

Penggalan novel tersebut merupakan dialog antara Kepala Bagian Pencegahan Penyakit Kementerian Dalam Negeri di Jepang dengan Ginko yang mengajukan diri untuk mengikuti ujian lisensi kedokteran agar dapat berkarir sebagai dokter perempuan. Kutipan tersebut menunjukkan bahwa perempuan pada zaman itu menyepakati tugas dan pekerjaannya sebatas mengenai urusan domestik, rumah tangga, mengandung, melahirkan hingga mengurus anak. Hal ini terbukti dari belum satu pun perempuan yang menjadi dokter di Jepang saat itu. Pemisahan posisi kerja yang dimaksud pada kutipan ini adalah perempuan dianggap tidak layak bekerja di ranah publik sebagai dokter, perempuan dipisahkan dari bidang pekerjaan kedokteran yang selama zaman tersebut hanya digeluti oleh kaum laki-laki.

2）＼cjkstart吟子は甲府の内藤塾に勤めてからはすべて実力で生活していた。 甲府での給料は多くはなかったが、女一人で舎監を兼ねていたので月々二、 三円程度の貯金をすることはできた。（Watanabe, 1970: 164）

Ginko menghidupi dirinya sendiri dengan bekerja di Sekolah Naito di Kofu. Gajinya tidak besar, tapi sebagai pengawas asrama dia mampu menabung dua atau tiga yen per bulan. (Watanabe, 2013: 143)

Hegemoni patriarki publik dalam bidang pekerjaan membuat upah perempuan lebih kecil daripada pendapatan kaum laki-laki ketika menjalani profesi yang sama. Kutipan tersebut mengisyaratkan bentuk hegemoni berupa pembedaan upah laki-laki dan perempuan. 


\section{Indonesian Language Education and Literature e-ISSN: 2502-2261 \\ http://www.syekhnurjati.ac.id/jurnal/index.php/jeill/ \\ Vol. 4, No. 1, Desember 2018, 62-74}

Meskipun tidak jelas disebutkan perbandingan upah antara laki-laki dan perempuan dalam profesi pengawas asrama, namun gaji tokoh Ginko memang kecil dan tidak sesuai dengan tanggung jawabnya.

Hegemoni patriarki publik dalam negara. Hegemoni patriarki publik dalam struktur negara ditunjukkan dengan ketidakhadiran perempuan dalam posisi-posisi penting di pemerintahan dan negara serta terbatasnya peran perempuan dalam hukum dan politik. Sebagai negara yang menganut patriarki, Jepang telah menerapkan berbagai aturan yang membatasi peran dan eksistensi perempuan untuk berkarya dan berkontribusi di negaranya sendiri.

3)「先進欧米諸国にはどこにも女医者がおります。それをいまさら旧幕 時代以前な瞉言を言っておったら諸外国のもの笑いになりましょう」。 (Watanabe, 1970: 274)

"Seluruh negara Barat yang maju punya dokter perempuan. Jepang akan ditertawakan habis-habisan jika menolak dihapuskannya kebijakan era Edo." (Watanabe, 2013: 236)

Saat zaman Meiji memasuki tahun 1900-an, negara Barat yang maju telah mempunyai dokter-dokter perempuan yang banyak memberi sumbangan besar kepada negeri. Sementara itu, Jepang masih menerapkan peraturan zaman Edo (1603-1867) yang sangat membatasi ruang lingkup perempuan di arena publik.

4) しかもこの中の『衆儀院議員選挙法』では、女子の政治的発言は一切 許されないというおおきな片手落ちがあった。(Watanabe, 1970:372)

Tidak hanya itu, hukum yang memungkinkan terpilihnya pejabat tidak memberikan hak bagi perempuan untuk memilih dan dengan sewenang-wenang melarang perempuan untuk menyatakan pandangan politik mereka juga. (Watanabe, 2013:312)

Penggalan novel tersebut menggambarkan situasi politik di Jepang pada tahun 1890 . Pada tahun itu, pertama kali ditetapkan Dewan Kekaisaran berdasarkan suara terbanyak. Ironisnya, pemerintah mengabaikan hak pilih perempuan. Namun, pembatasan tersebut juga tidak mendapat perlawanan berarti dari kaum perempuan itu sendiri. Meskipun ada yang melakukan perlawanan dan protes keras, aksi kaum perempuan tersebut masih sangat minim dan lemah. 


\section{Indonesian Language Education and Literature e-ISSN: 2502-2261 \\ http://www.syekhnurjati.ac.id/jurnal/index.php/jeill/ \\ Vol. 4, No. 1, Desember 2018, 62-74}

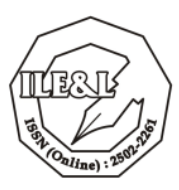

5) だがこの当時、多くの人々はそれを当然のことだとかんがえていた。 実際、自由民権運動に活躍していた人たちでさえ、これには大きな異論を 唱えず、新しく目覚めた女子の一部がひそかに不満を述べる。(Watanabe, 1970: 372)

Sebagian besar penduduk menganggap hal ini biasa saja... satu-satunya suara yang menentang hanya berasal dari perempuan itu sendiri, tetapi hanya sedikit dan tidak terlalu berpengaruh. (Watanabe, 2013:312)

Penggalan tersebut menggambarkan adanya mayoritas penduduk yang menganggap larangan bagi perempuan berkontribusi pada politik pemerintahan Jepang sebagai hal yang biasa saja.

Hegemoni patriarki publik dalam kasus kekerasan laki-laki. Bentuk-bentuk hegemoni patriarki publik yang merepresentasikan adanya penindasan akibat kekerasan lakilaki, diantaranya: pelecehan seksual, penyerangan seksual, kekerasan fisik, dan kekerasan verbal. Semua kekerasan laki-laki yang terjadi dalam novel ini mendapat tanggapan yang berbeda-beda dari korbannya. Bentuk hegemoni itu sendiri adalah suatu kondisi saat perempuan tidak melakukan perlawanan sengit, pelaporan, maupun tuntutan hukum terhadap segala jenis kekerasan laki-laki yang menimpanya.

6)「なかなかいい顔しとる」

「この顔でいい顔しとる」

「男の脈でも見るわい」揶揄とも侮辱ともつかない言葉を次々と浴びせる ... 吟子は男共にかまわず教場の後ろ側の席に向かった。(Watanabe, 1970:174)

"Cantik ya?"

"Mmm...dan dia akan mengukur denyut nadi para laki-laki."

"Dan, melihat mereka telanjang juga!" Godaan dan hinaan menyerbu Ginko. ...Dengan mengabaikan para laki-laki itu, Ginko menuju tempat duduk di bagian belakang kelas (Watanabe, 2013:152)

Kutipan tersebut menunjukkan bahwa godaan seksual silih berganti menerpa Ginko. Tokoh utama tidak melawan pelecehan-pelecehan verbal yang dialami. Keputusan Ginko tidak melawan dan justru mengabaikan hal tersebut karena tidak ingin menyia-nyiakan usahanya selama ini yang sedang berjuang keras demi menggapai cita-cita menjadi dokter 


\section{Indonesian Language Education and Literature e-ISSN: 2502-2261 \\ http://www.syekhnurjati.ac.id/jurnal/index.php/jeill/ \\ Vol. 4, No. 1, Desember 2018, 62-74}

perempuan. Hal ini secara tidak langsung juga dapat dikatakan bahwa Ginko sedang berupaya memperoleh kesetaraan gender.

7) ...ひどいのになると、吟子が来るのを知って用もないのに先に入って出 て来ない奴もいる。しかも、吟子が出たあと、すぐとび込み『吟子女史、 只今月経中』と板戸に貼り紙をする。だれに文句を言うことも、だれに苦 情を訴えるわけにもいかない。(Watanabe, 1970:180)

...mereka akan berada di urinal itu sampai akhir waktu istirahat hanya karena ingin menggangu. Bahkan ada yang menyerbu masuk begitu Ginko keluar dan kemudian memasang tanda di pintu masuk yang mengumumkan "Nona Ginko sedang datang bulan". Ginko tidak bisa mengeluh kepada siapapun. (Watanabe, 2013:157)

Penyerangan seksual terjadi pada tokoh Ginko saat berada di toilet universitas kedokteran. Dapat dilihat bahwa Ginko juga tidak melakukan perlawanan berarti dan tidak menyampaikan hal ini kepada siapa pun.

8)「三人順にな、頼んだぜ」

振り向くと右手にいた男は後ろに廻って道を゙,閉ざしている。「誰にも 言わないから、いいだろう」、...「脱げ」、髭の男が大声で叫んだ。眼は すでに興奮で血走っている。こんなところで吟子の肉体を祭廻したしよう といういのである。「さあ早う!」、男が言った瞬間吟子は身をかがめる と右へ行くと見せて左へさけ、正面男の神下を気に潜り抜けた。…ところ で吟子は後ろから襟元を捕まえられた。「いやっ！」悲鳴とともに吟子の 首が後ろにのけぞった。男たちはすでに獣になっていた。ばたばたと折り 重なるように三人男が、吟子の手足を抑えにかかった。(Watanabe, 1970:182-183)

"Kami mau bergiliran, mengerti?"

Ginko berbalik lagi, tapi mereka menghalangi jalan di belakangnya. "Kami tidak akan memberi tahu siapapun, jadi kau tidak perlu sok jual mahal.".... "Lepaskan pakaianmu!" raung si kumis tebal, matanya merah. Mereka semua akan memerkosanya. "Cepat!"

Ginko tiba-tiba berjongkok, menghindar ke kanan dan kemudian melesat ke kiri bawah lengan yang ada di depannya.... Namun kakinya tidak sebanding dengan mereka. Mereka dengan cepat menangkapnya dan menarik kerah bajunya ke belakang. "Tidak!" Ginko berteriak saat dia ditarik ke belakang. Para laki-laki itu telah menjadi binatang dan berjuang untuk menekan bagian tubuh Ginko yang menggeliat-geliat. (Watanabe, 2013: 159-160) 


\section{Indonesian Language Education and Literature \\ e-ISSN: 2502-2261 \\ http://www.syekhnurjati.ac.id/jurnal/index.php/jeill/ \\ Vol. 4, No. 1, Desember 2018, 62-74}

Kekerasan fisik dialami tokoh Ginko, yaitu diperkosa oleh 3 orang mahasiswa Universitas Kedokteran Kojuin. Meskipun telah menghindar dan mencoba kabur semampunya, tenaga seorang perempuan ternyata tidak mampu melawan tenaga tiga orang laki-laki. Namun hal itu tidak terjadi karena Ginko mengaku mengidap penyakit kelamin gonorrhea yang ditularkan suaminya. Artinya, para pemerkosa itu juga akan tertular jika tetap melakukan perbuatan tersebut. Meskipun tidak terluka, tetapi kasus ini menekan kondisi kejiwaan Ginko. Walaupun demikian, Ginko saat itu tidak melaporkannya kepada siapa pun.

9) このことを吟子は警察はもちろん、、塾長にも言わなかった。言った ところで男生徒中へ女子が入り込むのは初めてから危険と思われていたこ とだし...(Watanabe, 1970:186)

Ginko tidak dapat melaporkan peristiwa itu kepada Rektor universitas maupun polisi. Sudah menjadi keputusannya untuk belajar bersama para lakilaki,...(Watanabe, 2013:162).

Ginko menyadari risiko tersebut karena berada dalam lingkungan mayoritas laki-laki. Kondisi ini menunjukkan Ginko berada dalam kondisi terhegemoni oleh kekerasan laki-laki. Selain kekerasan fisik, kekerasan verbal berupa umpatan dan makian kasar juga dialami tokoh Ginko. Hal ini seperti pada kutipan-kutipan berikut.

10)「お前は女郎と同じだ！」突然、中央の男はそういう唾を吐き捨て ... (Watanabe, 1970:186)

"Dasar perempuan jalang!" si kumis tebal itu mengumpat sambil berbalik. (Watanabe, 2013:161)

11)「いい加減にしやがれ、この阿女！」途端に吟子の足下にいま買って きたばかりの饅頭が吒きつけられた。「見せぬといったら見せぬ。さっさ と帰れ」(Watanabe, 1970:195)

"Tinggalkan aku sendiri. Dasar perempuan bodoh!” teriak orang itu, melemparkan kue itu ke kaki Ginko. "Kubilang aku tidak akan menunjukkan lukaku, titik..." (Watanabe, 2013:171)

Hegemoni patriarki publik dalam budaya. Budaya yang dimaksud adalah sebuah struktur ideal bahwa maskulinitas merupakan sifat wajib laki-laki dan feminitas merupakan sifat wajib perempuan. Dalam budaya patriarki, perempuan seutuhnya adalah perempuan yang 


\section{Indonesian Language Education and Literature e-ISSN: 2502-2261 \\ http://www.syekhnurjati.ac.id/jurnal/index.php/jeill/ \\ Vol. 4, No. 1, Desember 2018, 62-74}

memiliki kriteria feminin ideal, seperti: sifat pasif, lembut, emosional, mampu mengandung, melahirkan, memasak, mengurusi tugas rumah tangga, dan mengasuh anak. Jika tidak memiliki kriteria tersebut, perempuan dianggap mengalami kerugian budaya. Seperangkat kriteria feminin ideal tersebut dipropagandakan melalui pendidikan maupun media massa, seperti: buku, majalah, televisi, dan media lain.

Dalam pendidikan, perempuan lebih baik tidak mengenyam pendidikan dan diarahkan untuk menanggung tugas domestik dapat dilihat pada kutipan berikut.

12) 大半の土地にはまだ古い考えがどっしりと根を下ろしていた。「学間 好きの蒸す絵を生んだは家門の恥」とか「学校より奉公」といった考えが 厳と残っていた時代である。「女性は家にいるもの」という思想とはまる で反する。(Watanabe, 1970:146)

Sikap mayoritas masyarakat terhadap pendidikan bagi perempuan terbukti pada ucapan-ucapan seperti "Melahirkan anak perempuan yang suka belajar membawa aib pada seluruh keluarga", "Utamakan pelayanan daripada pelajaran", "Perempuan seharusnya diam di rumah". (Watanabe, 2013:127)

Perempuan yang gemar belajar adalah sebuah aib. Perempuan harus berdiam di rumah dan tidak terlibat pendidikan yang hanya boleh diakses oleh laki-laki. Sementara itu, dalam media massa, buku adalah satu-satunya alat dalam kisah novel ini yang digunakan untuk menyebarkan pemikiran patriarki yang menghegemoni kaum perempuan di ranah publik. Hal ini seperti pada kutipan novel berikut.

13) それにしても子供が生まれない、という烙印はぎんには淋しかった。 「子無きは去る」と『女大学』に書かれているように、当時では右女は立 派な離婚の理由になりえた。だがさおれは女の生理まで不足した屈辱的な 理由でもある。あの女は不具だから、と言うのと変えらない。(Watanabe, 1970: 39)

Dia ingat sebuah kalimat yang dibacanya di buku tingkah laku perempuan berjudul Menjadi Perempuan Sejati, "seorang perempuan yang tidak bisa punya anak harus meninggalkan rumah suaminya". Kala itu cap "mandul" adalah alasan umum perceraian. Namun, memandang perempuan hanya dari kemampuannya menghasilkan anak tanpa melihat nilai-nilai lainnya adalah penghinaan. (Watanabe, 2013: 34-35) 


\section{Indonesian Language Education and Literature \\ e-ISSN: 2502-2261 \\ http://www.syekhnurjati.ac.id/jurnal/index.php/jeill/ \\ Vol. 4, No. 1, Desember 2018, 62-74}

Kutipan tersebut menggambarkan bahwa perempuan 'wajib' menghasilkan anak. Pernyataan itu tertulis dalam sebuah buku. Hal tersebut membuktikan adanya legitimasi dari masyarakat Jepang mengenai ideologi patriarki yang sangat berkuasa. Hal ini juga terlihat dari konten dalam buku tersebut yang sangat menyudutkan kaum perempuan. Walaupun demikian, buku tersebut tetap beredar luas tanpa sensor dari lembaga negara. Hal ini menunjukkan bahwa masyarakat Jepang pada zaman tersebut menganggap sosok 'feminin ideal' adalah sosok yang mampu menghasilkan keturunan bagi keluarga. Jika tidak mampu menjadi sosok 'feminin ideal', perempuan wajar untuk diceraikan serta wajib meninggalkan rumah suami.

\section{SIMPULAN}

Bentuk-bentuk hegemoni patriarki publik ditemukan dalam novel Hanauzumi karya Junichi Watanabe. Terdapat empat bentuk hegemoni patriarki publik, yaitu: 1) bidang pekerjaan, seperti: pemisahan posisi dan pembedaan upah; 2) bidang negara, seperti: ketidakhadiran perempuan dalam posisi penting dan terbatasnya hak perempuan dalam bidang hukum dan politik; 3) kekerasan oleh laki-laki, seperti: pelecehan seksual, penyerangan seksual, percobaan pemerkosaan, dan kekerasan verbal berupa makian dan hinaan; serta 4) bidang budaya, seperti: perempuan wajib memiliki kriteria feminin ideal yang disebarkan melalui pendidikan dan buku. Semua bentuk hegemoni patriarki tersebut menyebabkan perempuan tersubordinasi. Kondisi ini menunjukkan bahwa penindasan oleh kekuasaan patriarki telah diterima dan mendapat persetujuan umum, termasuk kelompok terhegemoni.

\section{DAFTAR PUSTAKA}

Bruce, S. \& Yearley, S. (2006). The Sage Dictionary of Sociology. London: Sage Publications.

Darwin, M. (1999). "Maskulinitas: Posisi Laki-laki dalam Masyarakat Patriarkis", Center for Population and Policy Studies, dalam Makalah Ilmu Komunikasi Universitas Gadjah Mada, Edisi S.281, 1999.

Denzin \& Lincoln. (2000). Handbook of Qualitative Research. London: Sage Publication Inc.

Germer, A. (2006). Feminist Thought and Women's History in Japan in Historical Consciousness, Historiography, and Modern Japanese Values. Kyoto: International Research Center for Japanese Studies. 


\section{Indonesian Language Education and Literature \\ e-ISSN: 2502-2261 \\ http://www.syekhnurjati.ac.id/jurnal/index.php/jeill/ \\ Vol. 4, No. 1, Desember 2018, 62-74}

Kramarae, C., Treichler, P. A., \& Russo, A. (1985). A Feminist Dictionary. London: Pandora Press.

Mulyaningsih, I. (2015). Kajian Feminisme Pada Novel "Ronggeng Dukuh Paruk" dan "Perempuan Berkalung Surban". Indonesian Language Education and Literature, 1(1), 107 - 119. DOI: http://dx.doi.org/10.24235/ileal.v1i1.75.

Ratna, N. K. (2010). Sastra dan Cultural Studies. Yogyakarta: Pustaka Pelajar.

Patria, N. \& Arief, A. (2003). Antonio Gramsci: Negara dan Hegemoni. Jakarta: Pustaka Pelajar.

Sofia, A. (2009). Aplikasi Kritik Sastra Feminis: Perempuan Dalam Karya-Karya Kuntowijoyo. Yogyakarta: Citra Pustaka.

Walby, S. (2014). Teorisasi Patriarki (Terjemahan Mustika Prasela). Yogyakarta: Jalasutra.

Watanabe, J. (1970). Hanauzumi. Jepang: Shinchosa.

Watanabe, J. (2013). Ginko (Terjemahan Istiani Prajoko). Bandung: Serambi Ilmu Semesta

Wiyatmi. (2012). Kritik Sastra Feminis: Teori dan Aplikasinya dalam Sastra Indonesia. Yogyakarta: Penerbit Ombak. 